\title{
Boys with precocious or early puberty: incidence of pathological brain magnetic resonance imaging findings and factors related to newly developed brain lesions
}

\author{
Keun Hee Choi, MD', \\ Seung Joon Chung, MD', \\ Min Jae Kang, $\mathrm{MD}^{2}$, \\ Ju Young Yoon, $\mathrm{MD}^{3}$, \\ Ji Eun Lee, MD", \\ Young Ah Lee, MD', \\ Choong Ho Shin, MD, PhD', \\ Sei Won Yang, MD ${ }^{1}$
}

${ }^{1}$ Department of Pediatrics, Seoul National University College of Medicine, Seoul, '2Department of Pediatrics, Seoul National University Bundang Hospital, Seongnam, ${ }^{3}$ Center for Pediatric Oncology, National Cancer Center, Goyang, ${ }^{4}$ Department of Pediatrics, Samsung Medical Center, Sungkyunkwan University School of Medicine, Seoul, Korea

Received: 5 September, 2013 Revised: 16 October, 2013 Accepted: 18 December, 2013

Address for correspondence: Choong Ho Shin, MD, PhD Division of Endocrinology and Metabolism, Department of Pediatrics, Seoul National University College of Medicine, 103 Daehak-ro, Jongno-gu, Seoul 110-799, Korea

Tel: +82-2-2072-3357

Fax: +82-2-743-3455

E-mail:chshinpd@snu.ac.kr
Purpose: Brain magnetic resonance imaging (MRI) findings and factors predictive of pathological brain lesions in boys with precocious puberty (PP) or early puberty (EP) were investigated.

Methods: Sixty-one boys with PP or EP who had brain MRI performed were included. PP was classified into the central or peripheral type. Brain MRI findings were categorized into group I (pathological brain lesion known to cause puberty; newly diagnosed [group la] or previously diagnosed [group lb]); group II (brain lesion possibly related to puberty); and group III (incidental or normal findings). Medical history, height, weight, hormone test results, and bone age were reviewed.

Results: Brain lesions in groups I and II were detected in 17 of 23 boys (74\%) with central PP, 9 of 30 boys (30\%) with EP, and 7 of 8 boys (88\%) with peripheral PP. All brain lesions in boys with peripheral PP were germ cell tumors (GCT), and 3 lesions developed later during follow-up. Group I showed earlier pubertal onset $(P<0.01)$ and greater bone age advancement $(P<0.05)$ than group III. Group III had lower birth weight and fewer neurological symptoms than "la and II" (all $P<0.05$ ).

Conclusion: Earlier onset of puberty, greater bone age advancement, and/or neurological symptoms suggested a greater chance of pathological brain lesions in boys with central PP or EP. All boys with peripheral PP, even those with normal initial MRI findings, should be evaluated for the emergence of GCT during follow-up.

Keywords: Male, Precocious puberty, Brain, Magnetic resonance imaging, Neoplasms

\section{Introduction}

Precocious puberty (PP) is defined as the development of secondary sexual characteristics before the age of 8 years in girls and 9 years in boys ${ }^{1)}$. Depending on the presence of central activation of the hypothalamic-pituitary-gonadal axis, PP may be classified as gonadotropin dependent, also known as true or central PP (CPP), or gonadotropin independent, also known as pseudo-PP or peripheral PP (PPP). In contrast to CPP in girls, for whom $90 \%$ of sexual precocity is idiopathic, the prevalence of organic central nervous system (CNS) lesions is higher in boys $(40 \% \text { to } 90 \%)^{2,3)}$. Thus, brain magnetic resonance imaging (MRI) scans should be performed to rule out organic CNS causes in all boys with PP.

Several studies have evaluated predictors to identify girls with possible organic CNS lesions ${ }^{4-6)}$. The prevalence of organic CNS lesions in girls is much lower when puberty starts after the age of $6^{4,7}$. However, there are concerns about the risk of missing CNS lesions by not imaging low-risk girls between the ages of 6 and 8 years. In a recent single-center cohort study of girls with precocious or early puberty $(\mathrm{EP})^{6}, 13$ of 208 girls $(6.3 \%)$ with precocious or EP but 
no other signs of CNS symptoms had a pathological MRI result. These girls were all older than 6 years, and 6 girls were 8 to 9 years old. There is no consensus on the appropriate age limit for performing brain MRI in these children. Although data on CNS abnormalities in boys with PP are available ${ }^{8)}$, no data exist on the prevalence of CNS abnormalities in boys with EP, defined as the appearance of pubertal signs between 9 and 10.9 years of age. Thus, further investigation of clinical and biochemical characteristics related to CNS abnormalities in boys with PP or EP is needed.

Peripheral causes of PP in boys can be induced by intracranial human chorionic gonadotropin (hCG)-producing tumors ${ }^{2}$. Even though there may be no apparent lesions in the initial MRI, the endocrinologist cannot guarantee that lesions will not develop later during the follow-up.

We evaluated brain MRI findings in boys with testicular enlargement $\geq 4 \mathrm{~mL}$ before 10.9 years of age. We also analyzed the characteristics related to the detection of organic CNS lesions at diagnosis and the later development of lesions during follow-up.

\section{Materials and methods}

This study was approved by the Seoul National University Hospital Institutional Review Board (IRB No. 1212-023449). We retrospectively reviewed the medical records of all boys referred to the Division of Pediatric Endocrinology and Metabolism of Seoul National University Children's Hospital for clinical signs of PP or EP between January 1995 and April 2012.

Onset and progression of pubertal signs (testis enlargement, voice break, and pubic hair), growth velocity in the past year, concurrent symptoms (headache, vomiting, diplopia, visual field defect, and enuresis), birth history (birth weight and gestational age), and previous illness (intracranial infection, tumor, hydrocephalus [HCP], and/or cranial irradiation) were recorded. All boys underwent a physical examination and pubertal staging by a pediatric endocrinologist. Height $(\mathrm{cm})$ was measured twice to the first decimal place with a Harpenden stadiometer (Holtain Ltd., Crymych, Wales, UK), and weight (kg) to the first decimal place with a digital scale. BMI was calculated as weight $(\mathrm{kg})$ divided by height squared $\left(\mathrm{m}^{2}\right)$. Height, weight, and BMI $z$ scores were assigned according to the 2007 Korean National Growth Charts".

Bone age was assessed using the Greulich-Pyle scale. Plasma 17-hydroxyprogesterone and dehydroepiandrosterone sulfate concentrations were measured to exclude abnormal androgen secretion. Plasma thyroxin and thyroid-stimulating hormone (TSH) concentrations were measured to exclude hypothyroidism. Serum beta-hCG $(\beta-h C G)$ and alpha fetoprotein (AFP) concentrations were measured to screen for germ cell tumors (GCTs) and hepatoblastomas, and were measured by immunoradiometric assay kits (hCG: Riakey, Shin Jin Medics, Seoul, Korea; AFP: Beckman Coulter, Prague, Czech Republic). The sensitivity of the $\beta$-hCG and AFP assays was $0.23 \mathrm{mIU} / \mathrm{mL}$ and $0.2 \mathrm{IU} / \mathrm{mL}$, respectively. Nonfasting venous blood samples were obtained to measure the concentrations of follicular-stimulating hormone (FSH), luteinizing hormone ( $\mathrm{LH})$, and testosterone. $\mathrm{LH}$ and FSH concentrations were measured using an immunoradiometric assay (Coat-A-count, Siemens, Malvern, PA, USA), and testosterone was measured by radioimmunoassay (Coat-A-count, Siemens). The detection limits were $0.15 \mathrm{mIU} / \mathrm{mL}, 0.06 \mathrm{mIU} / \mathrm{mL}$, and $0.04 \mathrm{ng} / \mathrm{mL}$, respectively, for $\mathrm{LH}, \mathrm{FSH}$, and testosterone. The gonadotropinreleasing hormone $(\mathrm{GnRH})$ stimulation test was performed in 50 boys at the first visit. Serum LH and FSH levels were measured $0,30,45,60$, and 90 minutes after an intravenous bolus administration of LH-releasing hormone (100 g Relefact, Sanofi-Aventis, Frankfurt am Main, Germany). Boys with testicular enlargement before 9 years of age were diagnosed as having CPP if peak $\mathrm{LH}$ concentration was $\geq 5 \mathrm{IU} / \mathrm{L}^{10)}$, or PPP if not. Boys with testicular enlargement between 9 and 10.9 years of age were defined as having $\mathrm{EP}^{11)}$. We excluded 13 boys with PPP $(n=5)$, history of cranial irradiation $(n=6)$ and GH treatment ( $\mathrm{n}=2)$ (Fig. 1).

No patients showed decreased growth velocity. All patients who were shown to have a pituitary lesion had a level of insulinlike growth factor-1 (IGF-1) that was compatible with their pubertal stage $^{12)}$.

Using the brain MRI results, we categorized the subjects into 3 groups. Group I included boys who had a pathological brain lesion related to pubertal development ${ }^{2}$; subgroup Ia had a newly diagnosed brain lesion, and subgroup Ib had a known brain etiology at the time of referral. Group II included those whose brain lesion had been reported in previous studies of

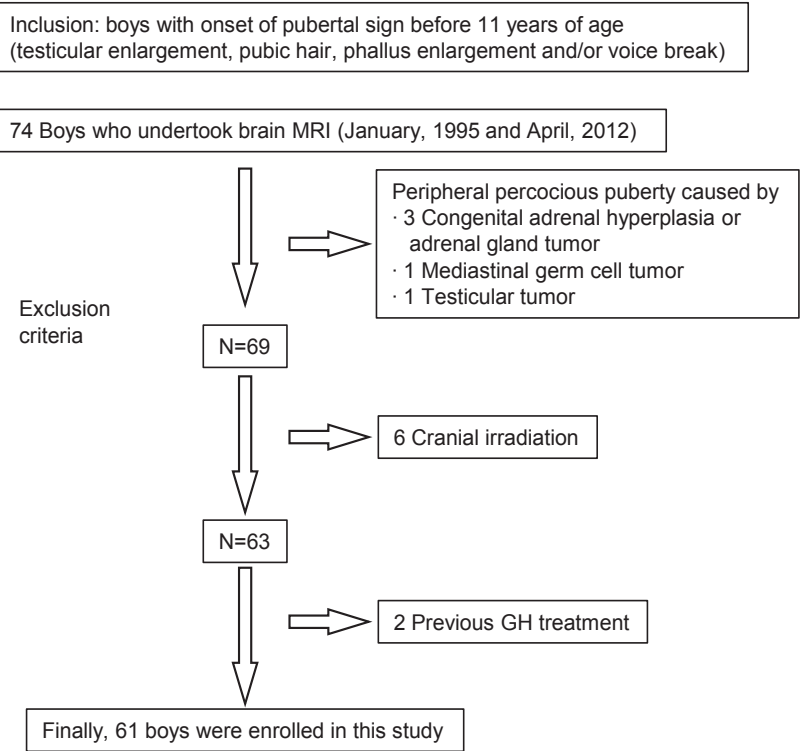

Fig. 1. Seventy-four boys with precocious puberty or early puberty who had brain magnetic resonance imaging (MRI) done were included. Thirteen boys were excluded: 5 boys with peripheral precocious puberty due to adrenal disease, testicular disease, extracranial germ cell tumor, 6 boys with history of cranial irradiation, and 2 boys with previous growth hormone treatment. In total, 61 boys were thus included in this study. 
PP patients but in which a causal relationship with PP was not proven $^{2,13-15)}$. Group III included those who had incidental brain findings not associated with puberty (subgroup IIIa) and those with normal brain MRI findings (subgroup IIIb).

\section{Statistical analyses}

Statistical analyses were performed using IBM SPSS ver. 19.0 (IBM Co., Armonk, NY, USA). Data are presented as median and range. The Mann-Whitney $U$ test was used to compare groups. The Fisher exact test was performed to compare categorical variables that defined the most significant separation between groups. A chi-square test for trend was used to compare categorical variables between groups according to the age at pubertal onset. A probability value of $P<0.05$ was considered significant.

\section{Results}

All 61 boys were categorized into the 3 groups: CPP $(n=23)$, $\operatorname{PPP}(\mathrm{n}=8)$, and EP $(\mathrm{n}=30)$. The 31 boys with PP were categorized further according to age of onset of puberty; $0-2.9$ years $(n=2)$, $3-5.9$ years $(n=4)$, and $6-8.9$ years $(n=25)$ (Table 1$)$.

\section{Brain lesions related to CPP, PPP or EP}

Group I included 23 boys who had a pathological brain lesion known to be related to pubertal development ${ }^{2}$ (Table 1). Group Ia included 12 boys who had a newly diagnosed brain pathology such as GCT $(n=7)$, hamartoma $(n=1)$, suprasellar arachnoid cyst $(A C)(n=2)$, or pilocytic astrocytoma $(n=2)$. All 7 boys with
GCT were categorized initially as having PPP at the first GnRHstimulation test. The results of biopsy were mature teratoma $(\mathrm{n}=3)$, immature teratoma $(\mathrm{n}=1)$, and choriocarcinoma $(\mathrm{n}=2)$. One patient did not have a biopsy, and the brain MRI diagnosis was mixed GCT or choriocarcinoma. Four of 7 boys were diagnosed with GCT after MRI evaluation at the first visit while 3 boys developed GCT later during follow-up (Table 2). Group Ib included 11 boys who had been diagnosed previously with the following brain pathology: optic glioma $(n=1)$, astrocytoma $(n=1)$, hamartoma $(n=1)$, previous history of meningitis or encephalitis $(n=3)$, HCP after intracranial hemorrhage $(n=1)$, postoperative HCP caused by treatment for a ganglioma, teratoma, or retinoblastoma $(n=3)$, and suprasellar AC $(n=1)$. Group II included 10 boys who had a type of brain lesion that had not been proven definitively to cause puberty ${ }^{2,13-15)}$. These included pituitary microadenoma $(n=2)$, retrocerebellar AC $(n=1)$, Rathke's cleft cyst $(n=3)$, pineal cyst $(n=2)$, empty sella syndrome $(n=1)$, and neurofibromatosis (NF) stigmata $(n=1)$. Group III included 28 boys who had incidental brain findings not known to be associated with puberty (group IIIa, n=6) and those boys with normal brain MRI findings (group IIIb, $\mathrm{n}=22$ ). Group IIIa included 6 boys who had incidental brain findings such as prominent subarachnoid space $(n=2)$, prominent perivascular space in the basal ganglia $(\mathrm{n}=1)$, focal high intensity in the white matter $(n=1)$, a cystic lesion in the white matter $(n=1)$, or a cyst in the choroidal fissure $(n=1)$.

\section{Factors related to pathological brain lesions in boys with PP or EP}

In our study, which excluded other peripheral organic causes of PP (adrenal gland, testis, liver, or other sites), 7 of 8 boys

Table 1. Brain magnetic resonance imaging findings in 61 boys with precocious or early puberty

\begin{tabular}{|c|c|c|c|c|c|c|}
\hline & & \multicolumn{4}{|c|}{ Precocious puberty $(n=31)$} & \multirow{3}{*}{$\begin{array}{l}\text { Early puberty } \\
9-10.9 \text { yr }(n=30)\end{array}$} \\
\hline & & \multicolumn{2}{|c|}{ Peripheral $(n=8)$} & \multicolumn{2}{|c|}{ Central $(n=23)$} & \\
\hline & & $3-5.9$ yr $(n=4)$ & $6-8.9$ yr $(n=4)$ & $0-2.9$ yr $(n=2)$ & $6-8.9$ yr $(n=21)$ & \\
\hline la & $\begin{array}{l}\text { Newly developed brain } \\
\text { lesion }(n=12)\end{array}$ & $\begin{array}{c}\mathrm{GCT}(2) \\
\mathrm{N} \rightarrow \mathrm{GCT}(1)^{\mathrm{a})}\end{array}$ & $\underset{\mathrm{N} \rightarrow \mathrm{GCT}(2)}{\mathrm{GCT}(2)^{\mathrm{a})}}$ & Hamartoma (1) & $\begin{array}{l}\text { Astrocytoma (1), } \\
\text { suprasellar AC (2) }\end{array}$ & Astrocytoma (1) \\
\hline $\mathrm{lb}$ & $\begin{array}{l}\text { Previously diagnosed } \\
\text { brain lesion }(n=11)\end{array}$ & & & & $\begin{array}{l}\text { Optic glioma (1), } \\
\text { astrocytoma (1), } \\
\text { hamartoma (1), } \\
\text { hydrocephalus (3) }{ }^{\text {b) }} \\
\text { previous meningitis/ } \\
\text { encephalitis (3) }\end{array}$ & $\begin{array}{l}\text { Hydrocephalus (1)' } \\
\text { suprasellar AC (1) }\end{array}$ \\
\hline$\|$ & $\begin{array}{l}\text { Brain lesion previously shown in case } \\
\text { reports }(n=10)\end{array}$ & & & & $\begin{array}{l}\text { Pituitary } \\
\text { microadenoma (2), } \\
\text { rathke cleft cyst (1), } \\
\text { retrocerebellar AC (1) }\end{array}$ & $\begin{array}{l}\text { Rathke cleft cyst (2), } \\
\text { pineal cyst (2), } \\
\text { empty sellar syndrome (1), } \\
\text { NF stigmata (1) }\end{array}$ \\
\hline IIla & Incidental findings $(\mathrm{n}=6)$ & & & $\begin{array}{l}\text { Prominent } \\
\text { subarachnoid } \\
\text { space (1) }\end{array}$ & & Others $(5)^{d)}$ \\
\hline Illb & Normal $(n=22)$ & Normal (1) & & & Normal (5) & Normal (16) \\
\hline
\end{tabular}

GCT, germ cell tumor.

${ }^{\text {a) }} \mathrm{N} \rightarrow$ GCT: normal at first evaluation $\rightarrow$ newly develop germ cell tumor. ${ }^{\text {b) }}$ Postoperative $(n=2)$, intracranial hemorrhage $(n=1)$. ${ }^{\text {c) Postoperative }}$ $(n=1) .{ }^{d}$ Prominent subarachnoid space $(n=1)$, prominent perivascular space in basal ganglia( $\left.n=1\right)$, focal high intensity in white matter $(n=1)$, cystic lesion in white matter $(n=1)$, and cyst in coroidal fissure $(n=1)$. 
Table 2. Boys who newly developed germ cell tumor during follow-up

\begin{tabular}{|c|c|c|c|}
\hline Variable & Patient 1 & Patient 2 & Patient 3 \\
\hline \multicolumn{4}{|l|}{ Initial evaluation } \\
\hline Age at pubertal onset & $3 \mathrm{yr}-5 \mathrm{yr} 11 \mathrm{mo}$ & $6 \mathrm{yr}-8 \mathrm{yr} 11 \mathrm{mo}$ & $6 \mathrm{yr}-8 \mathrm{yr} 11 \mathrm{mo}$ \\
\hline Age at first visit & 4 yr 5 mo & $6 \mathrm{yr} 11 \mathrm{mo}$ & $7 \mathrm{yr} 3 \mathrm{mo}$ \\
\hline Level of ß-hCG (mIU/mL) & 78.1 & 11 & 46 \\
\hline \multicolumn{4}{|l|}{ At the time of tumor diagnosis } \\
\hline Age at tumor diagnosis & $4 \mathrm{yr} 7 \mathrm{mo}$ & 13 yr $11 \mathrm{mo}$ & $8 \mathrm{yr} 1 \mathrm{mo}$ \\
\hline Follow-up duration & $2 \mathrm{mo}$ & 6 yr 11 mo & $9 \mathrm{mo}$ \\
\hline $\begin{array}{l}\text { Previous brain MRI before } \\
\text { tumor detection }\end{array}$ & $2 \mathrm{mo}$ & $25 \mathrm{mo}$ & $2 \mathrm{mo}$ \\
\hline Level of ß-hCG (mIU/mL) & 116.1 & 13.2 & 14,040 \\
\hline Neurologic symptoms & None & Headache, vomiting, diplopia & Vomiting, altered mentality \\
\hline Brain MRI finding & $\begin{array}{l}\text { Mildly increased size of pineal gland } \\
\text { showing enhancement, } \\
1.3 \mathrm{~cm} \times 1.1 \mathrm{~cm} \text { sized }\end{array}$ & $\begin{array}{l}\text { Hydrocephalus and pineal gland mass } \mathrm{H} \\
2.7 \mathrm{~cm} \times 2.0 \mathrm{~cm} \text { sized }\end{array}$ & $\begin{array}{l}\text { Hydrocephalus and pineal gland mass } \\
3.6 \mathrm{~cm} \times 3.4 \mathrm{~cm} \text { sized }\end{array}$ \\
\hline Tumor pathology & Not done & Immature teratoma & Choriocarcinoma. \\
\hline
\end{tabular}

ß-hCG, beta-human chorionic gonadotropin; MRI, magnetic resonance imaging.

Table 3. Comparison of clinical and biochemical characteristics according to brain MRI findings in boys with central precocious puberty or early puberty

\begin{tabular}{|c|c|c|c|c|c|c|c|c|}
\hline \multirow[b]{2}{*}{ Characteristic } & \multicolumn{3}{|c|}{ Pathologic lesion (I), $(n=16)$} & \multirow{2}{*}{$\begin{array}{l}\text { Brain lesion } \\
\text { reported in } \\
\text { case } \\
\text { report (II) }\end{array}$} & \multicolumn{3}{|c|}{ Nonpathologic lesion (III), $(n=27)$} & \multirow{2}{*}{$\begin{array}{c}\text { Newly } \\
\text { developed } \\
\text { brain lesion } \\
(\text { la+II) }\end{array}$} \\
\hline & $\begin{array}{c}\text { Newly } \\
\text { developed (la) }\end{array}$ & $\begin{array}{l}\text { Previously } \\
\text { Diagnosed } \\
\text { (Ib) }\end{array}$ & Total (I) & & $\begin{array}{l}\text { Incidental } \\
\text { findings (IIIa) }\end{array}$ & Normal (IIIb) & Total (III) & \\
\hline No. of patients & 5 & 11 & 16 & 10 & 6 & 21 & 27 & 15 \\
\hline $\begin{array}{l}\text { Age at pubertal onset (n), } \\
(<3: 3 \text { to }<6: 6 \text { to }<9 \text { : } \\
9 \text { to }<11 \text { yr) }\end{array}$ & $1: 0: 3: 1^{a, c)}$ & $0: 0: 9: 2$ & $1: 0: 12: 3$ & $0: 0: 4: 6$ & $1: 0: 0: 5$ & $0: 0: 5: 16$ & $1: 0: 5: 21^{d)}$ & $1: 0: 7: 7$ \\
\hline Neurologic symptom (n) & 2 & 2 & 4 & 2 & 0 & 1 & $1^{f)}$ & 4 \\
\hline Birth weight $(\mathrm{kg})$ & $\begin{array}{c}3.53 \\
(2.10 \text { to } 3.90)\end{array}$ & $\begin{array}{c}3.00 \\
(1.96 \text { to } 3.50)\end{array}$ & $\begin{array}{c}3.10 \\
(1.96 \text { to } 3.90)\end{array}$ & $\begin{array}{c}3.50 \\
(2.40 \text { to } 3.90)\end{array}$ & $\begin{array}{c}2.95 \\
\text { (2.00 to } 3.10)\end{array}$ & $\begin{array}{c}2.89 \\
(2.10 \text { to } 3.99)\end{array}$ & $\begin{array}{c}2.94 \\
(2.00 \text { to } 3.99)^{f)}\end{array}$ & $\begin{array}{c}3.50 \\
\text { (2.10 to } 3.90)\end{array}$ \\
\hline Birth weight < 2.5 kg (n) & 1 & 2 & 3 & 1 & 1 & 3 & 4 & 2 \\
\hline $\begin{array}{l}\text { Bone age-chronological } \\
\text { age (yr) }\end{array}$ & $\begin{array}{c}3.83 \\
(3.08 \text { to } 5.08)^{\mathrm{a}, \mathrm{b})}\end{array}$ & $\begin{array}{c}3.83 \\
(-0.58 \text { to } 5.00)\end{array}$ & $\begin{array}{c}3.83 \\
(-0.58 \text { to } 5.08)\end{array}$ & $\begin{array}{c}1.58 \\
(-0.92 \text { to } 3.83)\end{array}$ & $\begin{array}{c}1.84 \\
(-0.58 \text { to } 3.10)\end{array}$ & $\begin{array}{c}2.33 \\
(-2.75 \text { to } 4.58)\end{array}$ & $\begin{array}{c}2.33 \\
(-2.75 \text { to } 5.58)^{\mathrm{e})}\end{array}$ & $\begin{array}{c}2.33 \\
(-0.92 \text { to } 5.08)\end{array}$ \\
\hline Height $z$ scores & $\begin{array}{c}2.37 \\
(-0.17 \text { to } 4.24)\end{array}$ & $\begin{array}{c}1.19 \\
(-2.15 \text { to } 3.06)\end{array}$ & $\begin{array}{c}1.64 \\
(-2.15 \text { to } 4.24)\end{array}$ & $\begin{array}{c}1.01 \\
(-1.39 \text { to } 3.45)\end{array}$ & $\begin{array}{c}1.13 \\
(-1.98 \text { to } 2.69)\end{array}$ & $\begin{array}{c}0.31 \\
(-1.0 \text { to } 3.58)\end{array}$ & $\begin{array}{c}0.31 \\
(-1.98 \text { to } 3.58)\end{array}$ & $\begin{array}{c}1.14 \\
(-1.39 \text { to } 4.24)\end{array}$ \\
\hline Body mass index $z$ scores & $\begin{array}{c}1.21 \\
(0.42 \text { to } 1.91)^{\mathrm{a}, \mathrm{b})}\end{array}$ & $\begin{array}{c}0.67 \\
(-1.20 \text { to } 2.03)\end{array}$ & $\begin{array}{c}1.21 \\
(-1.20 \text { to } 2.03)\end{array}$ & $\begin{array}{c}0.13 \\
(-0.85 \text { to } 1.00)\end{array}$ & $\begin{array}{c}0.54 \\
(-1.73 \text { to } 1.45)\end{array}$ & $\begin{array}{c}0.07 \\
(-1.41 \text { to } 1.68)\end{array}$ & $\begin{array}{c}0.15 \\
(-1.73 \text { to } 1.68)^{e)}\end{array}$ & $\begin{array}{c}0.42 \\
(-0.85 \text { to } 1.91)\end{array}$ \\
\hline Basal LH (mlU/mL $)^{9)}$ & $\begin{array}{c}2.20 \\
(0.25 \text { to } 4.90)\end{array}$ & $\begin{array}{c}1.70 \\
\text { (0.70 to } 8.10)\end{array}$ & $\begin{array}{c}1.95 \\
(0.25 \text { to } 8.10)\end{array}$ & $\begin{array}{c}0.79 \\
(0.25 \text { to } 4.16)\end{array}$ & $\begin{array}{c}1.90 \\
(0.78 \text { to } 2.34)\end{array}$ & $\begin{array}{c}1.25 \\
\text { (0.63 to } 2.30)\end{array}$ & $\begin{array}{c}1.40 \\
\text { (0.63 to } 2.34)\end{array}$ & $\begin{array}{c}1.07 \\
(0.25 \text { to } 4.90)\end{array}$ \\
\hline Basal FSH (mIU/mL) & $\begin{array}{c}2.20 \\
(1.20 \text { to } 4.40)\end{array}$ & $\begin{array}{c}2.60 \\
(1.50 \text { to } 4.30)\end{array}$ & $\begin{array}{c}2.60 \\
(1.20 \text { to } 4.40)\end{array}$ & $\begin{array}{c}2.44 \\
(0.80 \text { to } 4.40)\end{array}$ & $\begin{array}{c}0.90 \\
(0.25 \text { to } 2.72)\end{array}$ & $\begin{array}{c}2.70 \\
(0.25 \text { to } 7.50)\end{array}$ & $\begin{array}{c}2.10 \\
(0.25 \text { to } 7.50)\end{array}$ & $\begin{array}{c}2.40 \\
\text { (0.80 to } 4.40)\end{array}$ \\
\hline \multicolumn{9}{|l|}{$\begin{array}{l}\text { After GnRH } \\
\text { stimulation }^{\text {h) }}\end{array}$} \\
\hline Peak LH (mIU/mL) & $\begin{array}{c}20.7 \\
(6.10 \text { to } 35.6)\end{array}$ & $\begin{array}{c}18.2 \\
\text { (12.0 to } 37.3)\end{array}$ & $\begin{array}{c}18.9 \\
\text { (6.10 to } 37.3)\end{array}$ & $\begin{array}{c}18.4 \\
(13.8 \text { to } 26.9)\end{array}$ & 37.6 & $\begin{array}{c}23.6 \\
(13.3 \text { to } 44.1)\end{array}$ & $\begin{array}{c}23.6 \\
(13.3 \text { to } 44.1)\end{array}$ & $\begin{array}{c}18.8 \\
\text { (6.10 to } 35.6)\end{array}$ \\
\hline Peak FSH $(\mathrm{mlU} / \mathrm{mL})^{\mathrm{h})}$ & $\begin{array}{c}7.30 \\
\text { (3.70 to } 15.6)\end{array}$ & $\begin{array}{c}5.30 \\
(3.70 \text { to } 8.10)\end{array}$ & $\begin{array}{c}5.65 \\
\text { (3.70 to } 15.6)\end{array}$ & $\begin{array}{c}6.10 \\
(2.50 \text { to } 14.4)\end{array}$ & 7.70 & $\begin{array}{c}6.50 \\
(1.80 \text { to } 24.5)\end{array}$ & $\begin{array}{c}6.90 \\
(1.80 \text { to } 24.5)\end{array}$ & $\begin{array}{c}6.30 \\
(2.50 \text { to } 15.6)\end{array}$ \\
\hline Peak LH/FSH ratio ${ }^{\text {h) }}$ & $\begin{array}{c}2.28 \\
\text { (1.65 to } 3.47)\end{array}$ & $\begin{array}{c}3.43 \\
\text { (2.37 to } 6.22)\end{array}$ & $\begin{array}{c}3.29 \\
(1.65 \text { to } 6.22)\end{array}$ & $\begin{array}{c}3.75 \\
(1.17 \text { to } 7.19)\end{array}$ & 4.88 & $\begin{array}{c}3.61 \\
(1.19 \text { to } 7.39)\end{array}$ & $\begin{array}{c}3.70 \\
(1.19 \text { to } 7.39)\end{array}$ & $\begin{array}{c}2.63 \\
(1.17 \text { to } 7.19)\end{array}$ \\
\hline
\end{tabular}

Values are presented as median (range).

$\mathrm{LH}$, luteinizing hormone; FSH, follicular-stimulating hormone; $G n R H$, gonadotropin-releasing hormone.

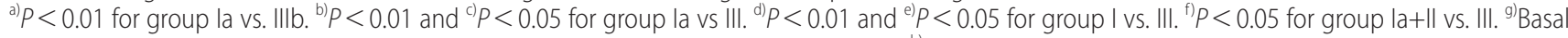
LH and FSH were performed in group II ( $n=8)$, group IIIa $(n=4)$, and group IIIb ( $n=17)$. ${ }^{\text {h) }} \mathrm{GnRH}$ stimulation test was performed in group II ( $\left.n=7\right)$, group IIla $(n=1)$, and group IIIb $(n=16)$. 
(A) Patient 1

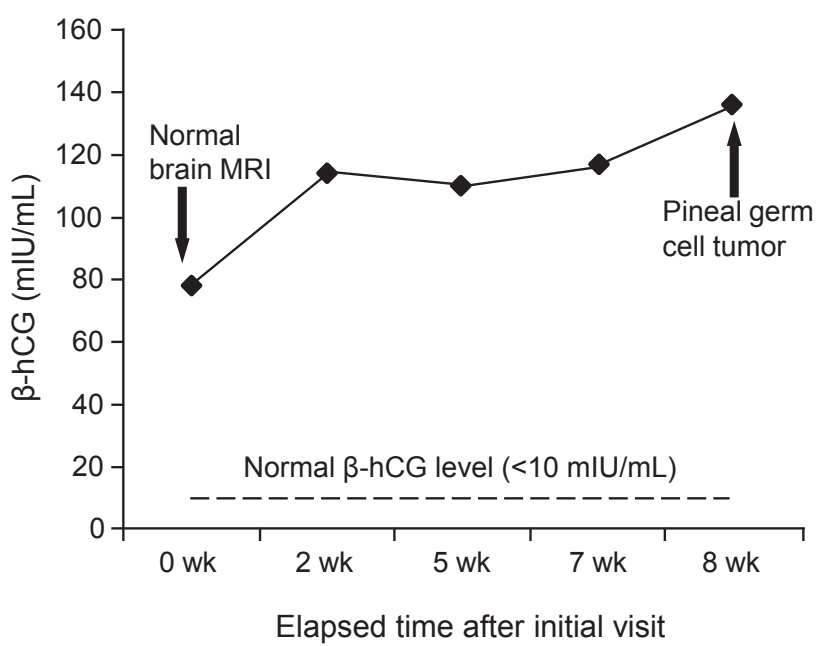

(C) Patient 3 (0-7 mo)

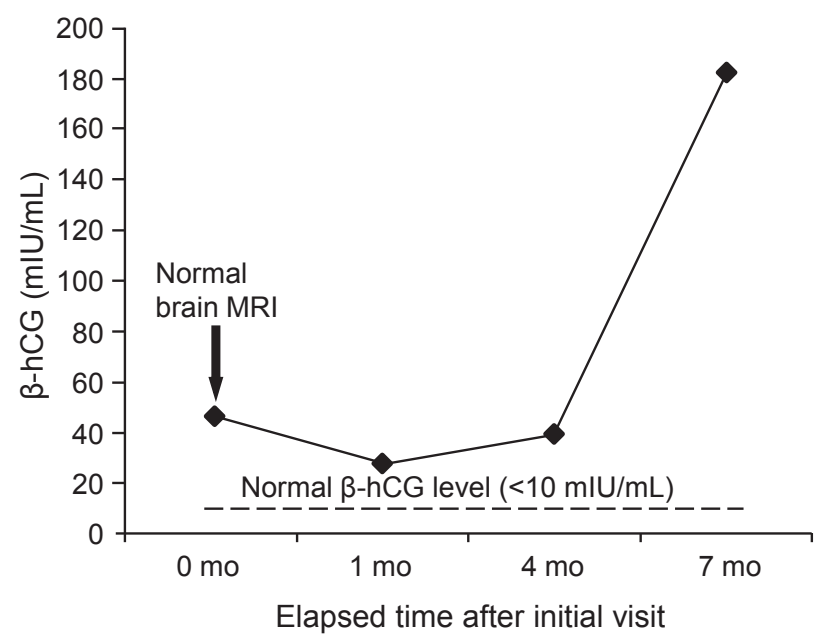

(B) Patient 2

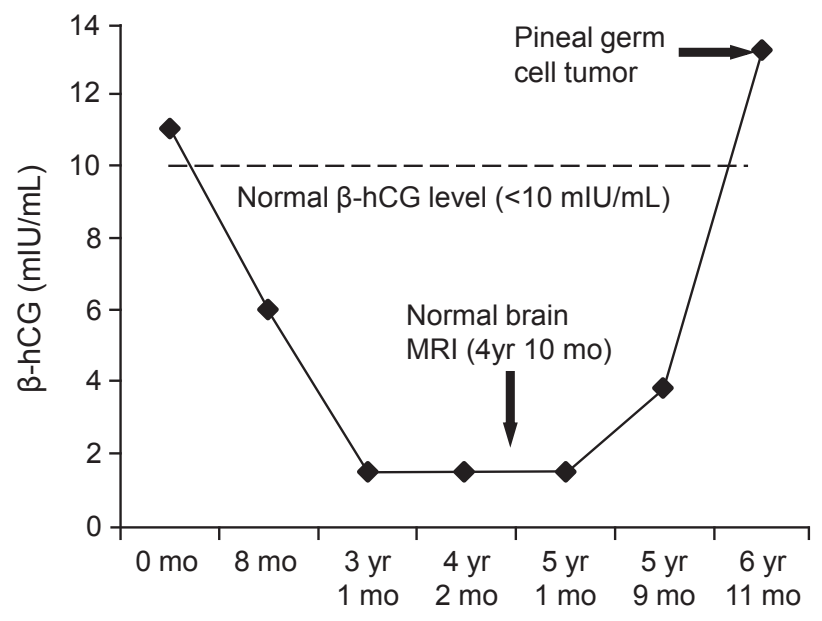

Elapsed time after initial visit

(D) Patient 3 (0-9 mo)

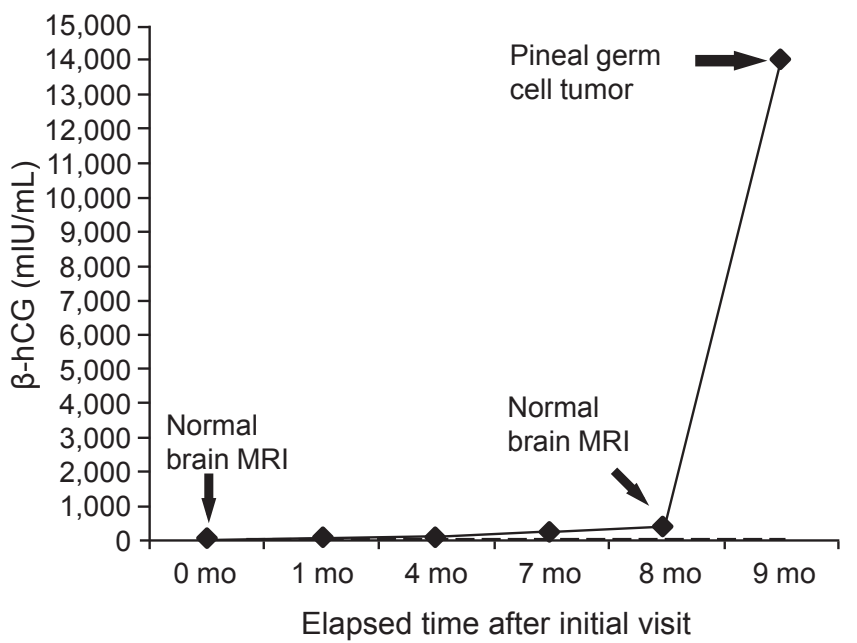

Fig. 2. Changes in beta-human chorionic gonadotropin ( $\beta$-hCG) in 3 patients. (A) $\beta$-hCG levels of patient 1 were persistently high, above normal range. (B) $\beta$-hCG levels of patient 2 were normal during follow-up and increased above normal range at tumor diagnosis. (C, D) In patient 3, $\beta$-hCG level slightly decreased to $27 \mathrm{mIU} / \mathrm{mL}$ during follow-up but increased to $397 \mathrm{mlU} / \mathrm{mL}$ at 8 months. At the ninth month, $\beta$-hCG level sharply increased to $14,040 \mathrm{mlU} / \mathrm{mL}$ and pineal germ cell tumor was found at that time.

with PPP were diagnosed with intracranial GCT (Table 1). Clinical and biochemical factors related to the presence of a pathological brain lesion were analyzed in the 53 boys with CPP or EP (Table 3). Boys with a newly diagnosed CNS pathology (group Ia) or those with a newly or previously diagnosed CNS lesion (group I) showed earlier pubertal onset, greater bone age advancement, and higher BMI $z$ scores than those without a pathological lesion (group III, all $P<0.05$ ) or those with normal brain imaging (group IIIb, all $P<0.01$ ). The differences in height $z$ scores $(P=0.058)$ and the percentage of boys with neurological symptoms $(P=0.056)$ between group Ia and group III were nearly significant. When we combined the group with newly diagnosed CNS pathology known to be related to puberty (group Ia) with the group with CNS pathology possibly related to puberty (group II), boys without such pathological CNS lesions (group III) had fewer neurological symptoms at diagnosis $(P=0.047)$ and had a birth history of lower birth weight $(P=0.012)$. Among the 28 boys with EP (excluding 2 boys with a previously diagnosed brain lesion), no significant characteristics were found to differentiate boys who had a newly developed brain lesion ( $n=7$, groups Ia and II) from those who did not ( $n=21$, group III).

\section{Three patients who developed GCT during follow-up}

In the 25 patients with normal brain MRI findings at the initial evaluation, no boys with CPP or EP developed a pathological lesion during follow-up. However, 3 boys with PPP, 
who had elevated levels of serum $\beta$-hCG without an apparent CNS lesion at diagnosis, later developed a GCT in the pineal gland during follow-up (Table 2, Fig 2). The interval between the diagnosis of PPP and visible tumor detection was 2 months, 6 years 11 months and 9 months for the 3 boys respectively. Although patient 1 and patient 3 showed persistently elevated levels of $\beta$-hCG during follow-up, the second had fluctuating $\beta$-hCG levels. Patient 2 had a slightly increased level of $\beta$-hCG at the time of initial presentation $(11 \mathrm{mIU} / \mathrm{mL})$; this level returned to the normal range during follow-up but later increased again $(13.2 \mathrm{mIU} / \mathrm{mL})$ at the time when the visible tumor was detected (Fig. 2).

\section{Discussion}

The percentages of boys with a newly developed pathological CNS lesion related to puberty (group Ia) were $88 \%$ (7 of 8 ), $29 \%$ (4 of 14), and 4\% (1 of 28) for PPP, CPP, and EP, respectively. Including previously diagnosed pathological CNS lesion (group $\mathrm{Ib}$ ), the percentage were increased to $57 \%$ (13 of 23), and 10\% (3 of 30) for CPP, and EP. The increase of percentage may be due to the fact that many patients with pathological brain lesions such as optic glioma, astrocytoma, hamartoma, HCP, suprasellar arachnoid cyst, and CNS infection were followed up in this tertiary referral university hospital. The percentages of boys with a brain lesion possibly related to puberty, for which a causal relationship has not been proven (pituitary microadenoma, Rathke's cleft cyst, retrocerebellar AC, pineal cyst, empty sella syndrome, and NF stigmata) were 17\% (4 of 23) and 20\% (6 of 30) for CPP and EP, respectively. Among boys with initially normal brain MRI findings, 3 boys who were diagnosed with PPP later developed a visible CNS lesion (all GCT) during the follow-up. Boys with a pathological brain lesion showed earlier onset of pubertal signs, greater bone age advancement, and higher BMI $z$ score than those with idiopathic PP or EP.

Tumors in the pineal region cause PP by interrupting CNS inhibitory pathways to the hypothalamus. In boys, another mechanism involves secretion of $\beta$-hCG, which stimulates the Leydig cells of the testes because of the high structural similarity of LH and hCG. Intracranial hCG-secreting tumors do not usually cause PP in girls presumably because complete ovarian function cannot occur without FSH priming. Thus, an hCG-secreting GCT in boys may present as PPP unrelated to hypothalamic-pituitary-gonadal activation ${ }^{16-18)}$. Occasionally, symptoms such as growth delay and enuresis related to endocrine dysfunction may not have a well-defined anatomic correlate, leading to a considerable delay in diagnosis ${ }^{19)}$. PPP may also lack a visible tumor correlate ${ }^{18)}$. Thus, even when a patient presents with normal neuroradiographic features at diagnosis, we propose that PPP warrants serial monitoring of $\beta$-hCG levels and/or brain MRI to detect an emerging intracranial GCT. However, no boys with CPP or EP with initially normal neuroradiographic features later developed a new intracranial lesion during follow-up.

The pathological CNS lesions responsible for CPP and PPP in our study were similar to those in previous studies ${ }^{20-23)}$ (Table 4). The underlying disease of the youngest boy presenting with CPP in our study was a hypothalamic hamartoma, which was reported previously in a 7 -month-old infant with $\mathrm{PP}^{24)}$. Hypothalamic hamartoma was the most commonly identified CNS lesion in previous studies whereas in our study, optic glioma and obstructive HCP were the most common lesions in CPP patients. This may be due to the fact that many optic glioma and HCP patients were followed up in this tertiary referral university hospital. A total of 7 GCT cases were found in the PPP patients. According to Rivarola ${ }^{20)}$, GCT was found in 5 of 18 patients (28\%) with suprasellar and pineal tumors. Suprasellar and pineal tumors were found in 16 patients in this study. The ratio of intracranial GCT to suprasellar and pineal tumors was 7 of 16 (44\%), which was high compared to previous study.

The possible association between PP and other brain lesions, including pituitary microadenoma ${ }^{4,6)}$, Rathke's cleft cyst $^{13)}$, pineal cyst $^{25,26)}$, empty sella syndrome ${ }^{14)}$, and NF stigmata in the absence of optic glioma ${ }^{15,27}$, have been described in previous PP case

Table 4. Previous studies of brain magnetic resonance imaging findings in patients with central and/or peripheral precocious puberty

\begin{tabular}{|c|c|c|c|c|c|c|c|c|c|c|c|}
\hline Study & Year & $\begin{array}{c}\text { No. of } \\
\text { all patients }\end{array}$ & $\begin{array}{c}\text { No. of boys } \\
\text { with brain } \\
\text { lesion }\end{array}$ & Hamartoma & $\begin{array}{c}\text { Suprasellar } \\
\text { arachnoid } \\
\text { cyst }\end{array}$ & $\begin{array}{c}\text { Optic } \\
\text { glioma }\end{array}$ & $\begin{array}{l}\text { Hydrocep } \\
\text { halus }\end{array}$ & $\begin{array}{l}\text { Germ cell } \\
\text { tumor }\end{array}$ & $\begin{array}{c}\text { CNS } \\
\text { infection }\end{array}$ & Others & $\begin{array}{c}\text { Neuro-fibromatosis } \\
\text { type } 1\end{array}$ \\
\hline \multicolumn{12}{|l|}{$\overline{C P P}$} \\
\hline De Sanctis et al. ${ }^{23)}$ & 2000 & 45 & 18 & 6 & - & 4 & 2 & - & $3^{\text {a) }}$ & $3^{\text {b) }}$ & 5 \\
\hline Taher et al. ${ }^{22)}$ & 2004 & 7 & 3 & & - & - & 1 & - & - & $2^{c)}$ & - \\
\hline Faizah et al. ${ }^{21)}$ & 2012 & 13 & 12 & 4 & 1 & 3 & $2^{\text {d) }}$ & 1 & & $2^{e)}$ & 1 \\
\hline Total & & 65 & 33 & 10 & 1 & 7 & 5 & 1 & 3 & 7 & 6 \\
\hline \multicolumn{12}{|l|}{ CPP \& PPP } \\
\hline Rivarola et al. ${ }^{20, f)}$ & 2001 & 18 & 18 & 7 & - & 6 & - & 5 & & 0 & - \\
\hline Our study & 2013 & 61 & 33 & 2 & 3 & 4 & 4 & 7 & 3 & 9) & 1 \\
\hline
\end{tabular}

PP, precocious puberty; CPP, central PP; PPP, pseudo-PP or peripheral PP.

a) Post meningitis with or without associated hydrocephalus. ${ }^{\text {b) Thalamic hyperplasia }(n=1) \text {, ependymoma and irradiation }(n=2) .{ }^{c} P i t u i t a r y}$ tumor $(n=1)$,

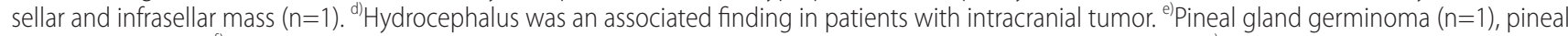
gland mass $(n=1) .{ }^{f)}$ All patients in this article were PP patients with tumors of the suprasellar and pineal areas. ${ }^{9}$ Retrobellar arachnoid cyst $(n=1)$, Rathke cleft cyst $(n=3)$, pineal cyst $(n=2)$, empty sella syndrome $(n=1)$, pituitary microadenoma $(n=2)$. 
reports. AC may be related to PP regardless of the location of the tumor in the suprasellar area or in another area such as the retrocerebellar area distant from the hypothalamus ${ }^{28}$. Although it is not known whether this relationship is causative ${ }^{4,17)}$, these lesions are not negligible and need to be monitored regularly because of the risk of size increments and possible pituitary hormone deficiencies.

The fact that 7 of 28 patients (25\%) with EP (excluding 2 with previously diagnosed lesions) were newly diagnosed with a CNS lesion leads us to recommend brain imaging for boys with EP. When boys with PPP caused by a lesion of mediastinal, hepatic, adrenal, or gonadal origin were excluded, 7 of 8 boys were diagnosed with an intracranial hCG-secreting tumor at diagnosis or during follow-up. Thus, we believe it is reasonable to conclude that all patients with gonadotropin-independent PP at initial evaluation should be investigated thoroughly for an organic cause.

Pathological brain lesions can be predicted by earlier pubertal onset in boys with CPP, as previous studies have reported in girls $^{2,4-6)}$. Unlike previous reports ${ }^{6,8)}$, in our study, basal LH or stimulated LH/FSH peaks did not differ significantly between boys with a pathological brain lesion and those without. Boys with a newly diagnosed brain lesion showed greater bone age advancement and higher BMI $z$ score, reflecting progressive puberty and exposure to sex hormones; however, they were not taller than those without a brain lesion. When boys with PP or EP are too short for their stage of pubertal development, the physician must rule out a combined pituitary hormone $(\mathrm{GH}$ and/or TSH) deficiency possibly caused by an organic brain lesion ${ }^{20,29)}$. However, there were no boys with pituitary hormone deficiency at diagnosis of PP or EP in our study, although screening was limited to IGF-1 level, the thyroid function test, and checking for normal growth velocity. We believe that the importance of all boys with PP or EP being evaluated for the presence of neurological symptoms suggesting a newly developed CNS lesion cannot be emphasized enough. In our study, boys without a pathological CNS lesion were more likely to have had a low birth weight; a previous report showed that low birth weight is related to early pubertal timing ${ }^{30)}$.

In conclusion, three-quarters of boys with CPP and one-quarter of boys with EP had a newly or previously diagnosed brain lesion that needed to be treated and/or monitored regularly. Earlier onset of puberty, greater bone age advancement, and higher BMI $z$ score indicate a greater chance of a pathological brain lesion in boys with CPP or EP. All boys with PPP, in whom an organic lesion may not be detected at diagnosis, should be evaluated thoroughly for the future emergence of a GCT.

\section{Conflict of interest}

No potential conflict of interest relevant to this article was reported.

\section{References}

1. Carel JC, Eugster EA, Rogol A, Ghizzoni L, Palmert MR; ESPE-LWPES GnRH Analogs Consensus Conference Group, et al. Consensus statement on the use of gonadotropin-releasing hormone analogs in children. Pediatrics 2009;123:e752-62.

2. Carel JC, Leger J. Clinical practice. Precocious puberty. N Engl J Med 2008;358:2366-77.

3. Carel JC, Lahlou N, Roger M, Chaussain JL. Precocious puberty and statural growth. Hum Reprod Update 2004;10:135-47.

4. Chalumeau M, Hadjiathanasiou CG, Ng SM, Cassio A, Mul D, Cisternino M, et al. Selecting girls with precocious puberty for brain imaging: validation of European evidence-based diagnosis rule. J Pediatr 2003;143:445-50.

5. Chalumeau M, Chemaitilly W, Trivin C, Adan L, Breart G, Brauner R. Central precocious puberty in girls: an evidence-based diagnosis tree to predict central nervous system abnormalities. Pediatrics 2002;109:61-7.

6. Mogensen SS, Aksglaede L, Mouritsen A, Sorensen K, Main KM, Gideon P, et al. Pathological and incidental findings on brain MRI in a single-center study of 229 consecutive girls with early or precocious puberty. PLoS One 2012;7:e29829.

7. Guillamo JS, Creange A, Kalifa C, Grill J, Rodriguez D, Doz F, et al. Prognostic factors of CNS tumours in Neurofibromatosis 1 (NF1): a retrospective study of 104 patients. Brain 2003;126(Pt 1):152-60.

8. Trivin C, Couto-Silva AC, Sainte-Rose C, Chemaitilly W, Kalifa C, Doz F, et al. Presentation and evolution of organic central precocious puberty according to the type of CNS lesion. Clin Endocrinol (Oxf) 2006;65:239-45.

9. Moon JS, Lee SY, Nam CM, Choi JM, Choe BK, Seo JW, et al. 2007 Korean National Growth Charts: review of developmental process and an outlook. Korean J Pediatr 2008;51:1-25.

10. Neely EK, Wilson DM, Lee PA, Stene M, Hintz RL. Spontaneous serum gonadotropin concentrations in the evaluation of precocious puberty. J Pediatr 1995; 127:47-52.

11. Mul D, Hughes IA. The use of GnRH agonists in precocious puberty. Eur J Endocrinol 2008;159 Suppl 1:S3-8.

12. Chun JK, Kim JB, Yoo HW. Normative data on serum levels of IGF-I, IGFBP-3 in healthy Korean children: effect of age, sex, height, body mass index, and pubertal maturation on the serum levels. J Korean Soc Pediatr Endocrinol 2000;5:75-82.

13. Trifanescu R, Ansorge O, Wass JA, Grossman AB, Karavitaki N. Rathke's cleft cysts. Clin Endocrinol (Oxf) 2012;76:15160.

14. Cacciari E, Zucchini S, Ambrosetto P, Tani G, Carla G, Cicognani A, et al. Empty sella in children and adolescents with possible hypothalamic-pituitary disorders. J Clin Endocrinol Metab 1994;78:767-71.

15. Zacharin M. Precocious puberty in two children with neurofibromatosis type I in the absence of optic chiasmal 
glioma. J Pediatr 1997;130:155-7.

16. Marx M, Beck JD, Grabenbauer GG, Fahlbusch R, Dorr HG. Gonadotrophin-independent puberty in a boy with a beta-HCG-secreting brain tumour. Horm Res 2000;54:448.

17. Imel EA, Bethin KE. Etiology of gonadotropin-dependent precocious puberty. In: Pescovitz O, Walvoord EC, editors. When puberty is precocious: scientific and clinical aspect. New Jersey: Humana Press; 2007:331-4.

18. Schwabe J, Calaminus G, Vorhoff W, Engelbrecht V, Hauffa BP, Gobel U. Sexual precocity and recurrent beta-human chorionic gonadotropin upsurges preceding the diagnosis of a malignant mediastinal germ-cell tumor in a 9-year-old boy. Ann Oncol 2002;13:975-7.

19. Crawford JR, Santi MR, Vezina G, Myseros JS, Keating RF, LaFond DA, et al. CNS germ cell tumor (CNSGCT) of childhood: presentation and delayed diagnosis. Neurology 2007;68:1668-73.

20. Rivarola, Belgorosky A, Mendilaharzu H, Vidal G. Precocious puberty in children with tumours of the suprasellar and pineal areas: organic central precocious puberty. Acta Paediatr 2001;90:751-6.

21. Faizah M, Zuhanis A, Rahmah R, Raja A, Wu L, Dayang A, et al. Precocious puberty in children: A review of imaging findings. Biomed Imaging Interv J 2012;8:e6.

22. Taher BM, Ajlouni HK, Hamamy HA, Shegem NS, Madanat AY, Ajlouni KM. Precocious puberty at an endocrine centre in Jordan. Eur J Clin Invest 2004;34:599-604.

23. De Sanctis V, Corrias A, Rizzo V, Bertelloni S, Urso L, Galluzzi F, et al. Etiology of central precocious puberty in males: the results of the Italian Study Group for Physiopathology of Puberty. J Pediatr Endocrinol Metab 2000;13 Suppl 1:687-93.

24. Rousso IH, Kourti M, Papandreou D, Tragiannidis A, Athanasiadou F. Central precocious puberty due to hypothalamic hamartoma in a 7-month-old infant girl. Eur J Pediatr 2008;167:583-5.

25. Lacroix-Boudhrioua V, Linglart A, Ancel PY, Falip C, Bougneres PF, Adamsbaum C. Pineal cysts in children. Insights Imaging 2011;2:671-8.

26. Dickerman RD, Stevens QE, Steide JA, Schneider SJ. Precocious puberty associated with a pineal cyst: is it disinhibition of the hypothalamic-pituitary axis? Neuro Endocrinol Lett 2004;25:173-5.

27. Cnossen MH, Stam EN, Cooiman LC, Simonsz HJ, Stroink $\mathrm{H}$, Oranje AP, et al. Endocrinologic disorders and optic pathway gliomas in children with neurofibromatosis type 1 . Pediatrics 1997;100:667-70.

28. Mohn A, Schoof E, Fahlbusch R, Wenzel D, Dorr HG The endocrine spectrum of arachnoid cysts in childhood. Pediatr Neurosurg 1999;31:316-21.

29. Huang HP, Tung YC, Tsai WY, Kuo MF, Peng SF. Arachnoid cyst with GnRH-dependent sexual precocity and growth hormone deficiency. Pediatr Neurol 2004;30:143-5.

30. Karaolis-Danckert N, Buyken AE, Sonntag A, Kroke A. Birth and early life influences on the timing of puberty onset: results from the DONALD (DOrtmund Nutritional and Anthropometric Longitudinally Designed) Study. Am J Clin Nutr 2009;90:1559-65. 